ISSN: 0215-7950

\title{
Penularan Potyvirus Penyebab Penyakit Mosaik pada Tanaman Nilam melalui Vektor Aphis gossypii
}

\section{Transmission of Potyvirus that Causes Mosaic Disease in Patchouli Plant through Vector Aphis gossypii}

\author{
Rita Noveriza $^{1,2 *}$, Gede Suastika ${ }^{1}$, Sri Hendrastuti Hidayat ${ }^{1}$, Utomo Kartosuwondo ${ }^{1}$ \\ ${ }^{1}$ Institut Pertanian Bogor, Bogor 16680 \\ ${ }^{2}$ Balai Penelitian Tanaman Rempah dan Obat, Bogor 16111
}

\begin{abstract}
ABSTRAK
Nilam (Pogostemon cablin) merupakan tanaman penting yang memiliki nilai ekonomi karena kemampuannya memproduksi minyak esensial, yaitu minyak nilam. Hama dan penyakit dapat berkontribusi terhadap rendahnya produksi minyak nilam di Indonesia. Potyvirus telah diidentifikasi merupakan salah satu penyebab penyakit mosaik pada nilam. Penelitian ini bertujuan untuk mengidentifikasi kutudaun yang berasosiasi pada tanaman nilam dan untuk mempelajari hubungan antara spesies kutudaun dan virus mosaik. Dua spesies kutudaun yang paling banyak ditemukan pada pertanaman nilam di Indonesia ialah Aphis gossypii dan Brachycaudus sp. Studi lebih lanjut pada kemampuan A. gossypii menularkan Potyvirus mengungkapkan adanya hubungan non persisten dengan periode puasa optimum 25 menit, periode makan akuisisi 15 menit, dan periode makan inokulasi optimum 4 jam.
\end{abstract}

Kata kunci: Aphis gossypii, Brachycaudus, nilam, Pogostemon cablin, Potyvirus

\begin{abstract}
Patchouli (Pogostemon cablin) is an economically important plant due to its capability to produce essential oil, i.e. patchouli oil. Pest and diseases may contribute to low production of patchouli oil in Indonesia. Aphids are commonly found associated with patchouli plants showing mosaic symptoms, indicated possible relationship between aphids and mosaic virus. Early diagnosis showed that mosaic disease on patchouli is caused by Potyvirus infection. A study was conducted to identify those aphid species and to examine relationship between the aphid species and mosaic virus. Two aphid species commonly found in patchouli plants in Indonesia are Aphis gossypii and Brachycaudus sp. Further study on the ability of $A$. gossypii to transmit Potyvirus revealed the possible non-persistent relationship, with 25 min optimum pre-acquisition starvation, 15 min acquisition period and 4 hours optimum inoculation feeding period, respectively.
\end{abstract}

Key words: Aphis gossypii, Brachycaudus, nilam, Pogostemon cablin, Potyvirus

\section{PENDAHULUAN}

Nilam (Pogostemon cablin) adalah salah satu tanaman penghasil minyak atsiri atau lebih dikenal dengan nama minyak nilam. Minyak nilam bersama dengan 14 jenis minyak atsiri lainnya adalah komoditas ekspor penghasil devisa. Salah satu negara pemasok utama minyak nilam di dunia adalah Indonesia (90\%). Ekspor Indonesia berfluktuasi dengan laju peningkatan ekspor sekitar $12 \%$ per tahun atau kisaran antara 700 dan 2800 ton minyak

\footnotetext{
*Alamat penulis korespondensi: Balai Penelitian Tanaman Rempah dan Obat, Jalan Tentara Pelajar No 3, Bogor 16111 Tel: 0251-8321879, Faks: 0251-8327010,Surel: rita_noveriza2000@yahoo.com
} 
nilam per tahun. Sementara itu, kebutuhan dunia berkisar 1200-1500 ton dengan pertumbuhan 5\% per tahun (PDIP 2010).

Pada tahun 2004 produktivitas nilam Indonesia sekitar $103.42 \mathrm{~kg} \mathrm{ha}^{-1}$, tetapi tahun berikutnya turun menjadi $103.11 \mathrm{~kg} \mathrm{ha}^{-1}$ dan pada tahun 2006 meningkat hingga $107.23 \mathrm{~kg}$ $\mathrm{ha}^{-1}$. Level produktivitas yang cukup tinggi tidak dapat dipertahankan sampai tahun 2007 menurun lagi menjadi $72.92 \mathrm{~kg} \mathrm{ha}^{-1}$. Pada tahun 2008 tingkat produktivitas 83.05 nilam kg ha-1. Selain masalah teknologi, ada beberapa faktor yang menyebabkan produktivitas dan mutu nilam Indonesia rendah, yaitu budi daya yang tidak intensif, serangan hama dan penyakit, benih yang buruk, juga cara penanganan bahan baku dan penyulingan minyak nilam yang masih jauh dari sempurna (PDIP 2010).

Salah satu masalah yang menyebabkan produksi nilam rendah ialah gangguan penyakit yang disebabkan oleh virus. Menurut hasil penelitian Noveriza et al. (2012), di Indonesia virus yang menyerang tanaman nilam menunjukkan gejala mosaik dan disebabkan oleh Potyvirus. Virus tersebut ditularkan oleh kutudaun sebagai vektor penyakit (Natsuaki et al. 1994). Hasil pengamatan penyakit mosaik pada tanaman nilam yang ada di Sumatera Barat, Sumatera Utara, Jawa Barat dan Jawa Tengah ditemukan adanya populasi kutudaun yang sangat tinggi pada tanaman yang terinfeksi (Noveriza et al. 2012).

Hasil ini menunjukkan adanya kemungkinan hubungan antara kutudaun dan penyakit virus mosaik yang menyerang tanaman nilam. Penelitian ini bertujuan mengidentifikasi kutudaun yang ditemukan ada pada tanaman nilam dan mengetahui hubungan virus penyebab penyakit mosaik pada tanaman nilam dengan kutudaun tersebut.

\section{BAHAN DAN METODE}

Kutudaun dikoleksi dari seluruh daerah yang disurvei dengan mengumpulkan seluruh jenis kutudaun yang ada pada tanaman nilam dan memasukkannya ke dalam botol koleksi yang berisi alkohol 70\% untuk keperluan identifikasi.

\section{Identifikasi Kutudaun}

Kutudaun yang digunakan dalam pengujian ini diperoleh dari pertanaman nilam. Sebelum dibiakkan pada tanaman inang nilam, kutudaun diidentifikasi menggunakan kunci identifikasi Blackman dan Eastop (2000) dan Martin (1983). Identifikasi dilakukan berdasarkan morfologi kutudaun yang tidak bersayap dengan karakter yang diamati antara lain kepala, sifunkuli dan kauda (Gambar 1).

\section{Pembuatan Preparat Mikroskopi}

Pembuatan preparat mikroskopi dilakukan dengan metode Blackman dan Eastop (2000). Kutudaun dimatikan dalam alkohol 95\%, kemudian dimasukkan ke dalam tabung reaksi yang berisi alkohol 95\%, dan dipanaskan dalam penangas air selama 5 menit. Alkohol bersama kutudaun dituang ke dalam gelas arloji, dan kutudaun ditusuk pada bagian torak dengan jarum. Selanjutnya kutudaun dimasukkan ke dalam tabung reaksi yang berisi $\mathrm{KOH} 10 \%$, dan dipanaskan kembali sampai kutudaun dalam tabung reaksi terlihat transparan. Tabung reaksi yang berisi kutudaun dikeluarkan dari penangas air dan kutudaun beserta $\mathrm{KOH}$ dituang ke gelas arloji. Kutudaun dicuci dengan air destilata sebanyak dua kali. Perlakuan selanjutnya adalah dehidrasi kutudaun, dengan cara merendam kutudaun yang telah dibersihkan isi tubuhnya dalam alkohol secara berurutan mulai dari kepekatan $50 \%, 70 \%, 80 \%$, 95\%, dan 100\% masingmasing selama 10 menit. Selanjutnya kutudaun direndam dalam minyak cengkeh selama 10 menit. Kutudaun diletakkan di atas gelas objek yang sebelumnya telah ditetesi minyak cengkeh. Kemudian minyak cengkeh diserap sampai bersih menggunakan kertas saring atau tisu. Posisi kutudaun diatur dan ditetesi balsam kanada. Pengerjaan tahap penyerapan minyak cengkeh dilakukan dibawah mikroskop stereo. Selanjutnya preparat ditutup dengan gelas penutup dan diamati di bawah mikroskop majemuk.

\section{Pembebasan Kutudaun dari Virus}

Pembebasan kutudaun dari virus berdasarkan metode Sularno (2009). Daun talas 
dicuci, tangkainya dibalut dengan kapas basah dan diletakkan pada cawan petri. Kutudaun dipindahkan dengan kuas gambar yang telah dibasahi dengan sedikit air ke permukaan daun talas bagian bawah yang berada dalam cawan petri. Cawan petri ditutup dan imago dibiarkan menghasilkan nimfa. Kutudaun yang baru lahir dipindahkan ke daun tanaman nilam sehat dan dibiarkan berkembang biak. Kutudaun ini yang kemudian digunakan untuk pengujian selanjutnya, karena kutudaun yang baru lahir selalu bebas virus.

\section{Perbanyakan Sumber Inokulum Potyvirus Isolat Bogor dan Tanaman Uji}

Sumber inokulum berasal dari tanaman nilam yang terinfeksi Potyvirus koleksi dari Cimanggu-Bogor (isolat Bogor). Isolat Bogor yang sebelumnya sudah dimurnikan pada tanaman Chenopodium amaranticolor tersebut diperbanyak pada tanaman nilam sebagai sumber inokulum. Tanaman uji yang digunakan dalam penelitian ini adalah nilam Aceh varietas Sidikalang hasil kultur in vitro (somaklon no 6, 21, dan 25) yang benihnya diperoleh dari Balittro Bogor. Setek tanaman nilam ditanam dalam kantong plastik berisi tanah:pupuk kandang (2:1). Setelah tanaman berumur 1 bulan, tanaman siap diinokulasi.

\section{Pengaruh Periode Puasa Kutudaun terhadap Penularan Potyvirus}

Nimfa kutudaun yang tidak bersayap dipindahkan ke kotak plastik untuk dipuasakan selama $10,15,25,40,60,90$, dan 120 menit. Selanjutnya 1200 kutudaun tersebut diletakkan pada tanaman nilam yang telah terinfeksi Potyvirus dengan periode makan akuisisi selama 15 menit. Kutudaun tersebut kemudian dipindahkan ke tanaman nilam sehat yang telah berumur 1 bulan sebanyak 10 ekor setiap tanaman, dengan periode inokulasi 24 jam. Pemindahan kutudaun dilakukan dengan menggunakan kuas. Tiap perlakuan diulang 15 kali. Sebagai kontrol digunakan vektor yang tidak dipuasakan dan diberi periode makan akuisisi pada tanaman nilam sehat. Tanaman uji dipelihara di dalam kurungan kedap serangga dan kutudaun dimatikan.
Pengamatan dilakukan setiap hari sampai 2 bulan setelah penularan terhadap masa inkubasi, gejala dan persentase tanaman yang sakit. Hasil penularan juga dikonfirmasikan dengan uji serologi (ELISA).

\section{Pengaruh Periode Inokulasi Kutudaun terhadap Penularan Potyvirus}

Nimfa kutudaun yang tidak bersayap dipindahkan ke kotak plastik untuk dipuasakan selama 40 menit. Selanjutnya 1200 kutudaun tersebut diletakkan pada tanaman nilam yang telah terinfeksi Potyvirus dengan periode makan akuisisi 15 menit. Kutudaun tersebut kemudian dipindahkan ke tanaman nilam sehat berumur 1 bulan sebanyak 10 ekor setiap tanaman, dengan periode inokulasi $5,10,15,30,60$ menit, $2,4,6,12$, dan 24 jam. Pemindahan kutudaun dilakukan dengan hati-hati menggunakan kuas agar stiletnya tidak patah. Tiap perlakuan diulang 10 kali. Sebagai kontrol, tanaman nilam diperlakukan sama, kecuali serangga vektor diberi periode makan akuisisi pada tanaman nilam sehat. Tanaman uji dipelihara di dalam kurungan kedap serangga dan kutudaun dimatikan. Pengamatan dilakukan setiap hari sampai 2 bulan setelah penularan terhadap masa inkubasi, gejala dan persentase tanaman yang sakit. Hasil penularan juga dikonfirmasikan dengan uji serologi (ELISA).

\section{HASIL}

\section{Identifikasi Kutudaun}

Hasil identifikasi menunjukkan ada 2 kutudaun yang ditemukan pada tanaman nilam yaitu Aphis gossypii dan Brachycaudus sp. Kutudaun tersebut membentuk koloni dipermukaan bawah daun dan tangkai pucuk; menyebabkan pucuk daun menggulung. Kutudaun yang digunakan untuk mengetahui hubungan virus dengan vektor hanya $A$. gossypii karena jumlahnya ditemukan lebih banyak dibandingkan Brachycaudus sp. (Tabel 1). Selain itu, keberadaan Brachycaudus sp. pada tanaman nilam baru diketahui saat ini, sedangkan $A$. gossypii sudah banyak yang melaporkan keberadaaanya pada tanaman nilam. 


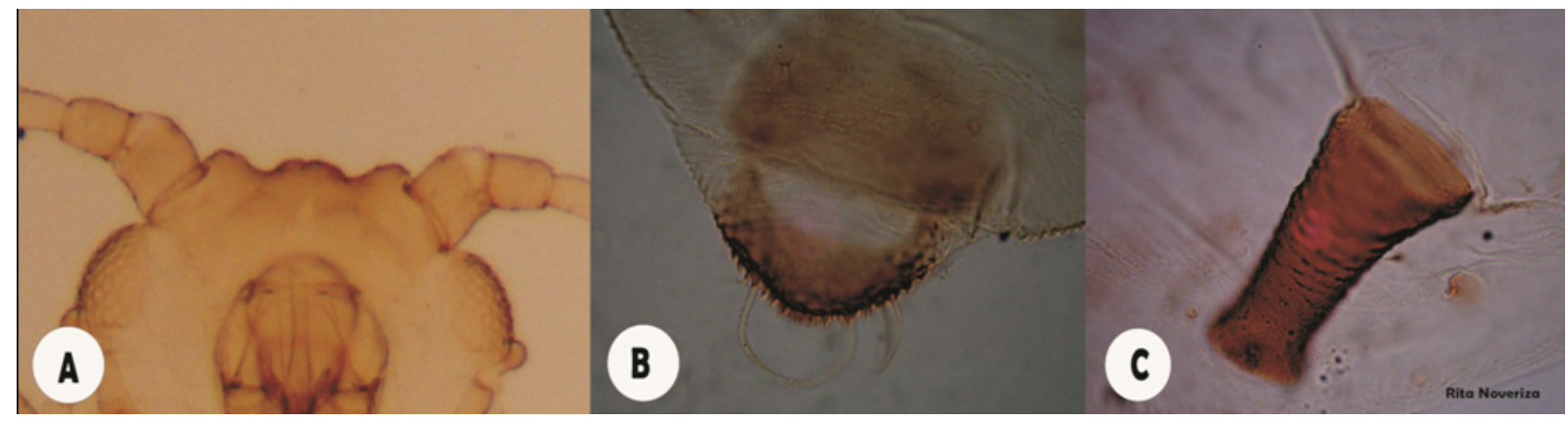

Gambar 1 Karakter morfologi kutudaun tidak bersayap yang diamati untuk kunci identifikasi: A, kepala; B, kauda; dan C, sifunkulus.

Tabel 1 Identifikasi kutudaun pada beberapa daerah sentra budidaya tanaman nilam di Indonesia

\begin{tabular}{lcc}
\hline \multirow{2}{*}{ Lokasi } & \multicolumn{2}{c}{ Jenis kutudaun } \\
\cline { 2 - 3 } Sumatera Barat & Aphis gossypii & Brachycaudus $\mathrm{sp}$. \\
$\quad$ Pasaman Barat & ++ & + \\
Sumatera Utara & & ++ \\
$\quad$ Pakpak Bharat & + & + \\
Jawa Barat & & + \\
$\quad$ Bogor & ++ & + \\
Kuningan & ++ & + \\
Garut & ++ & ++ \\
Jawa Tengah & & ++ \\
Brebes & + & ++ \\
Purbalingga & & + \\
Jambi & + & + \\
$\quad$ Sarolangun & + & + \\
\hline
\end{tabular}

++ , tinggi ( $>50$ ekor kutudaun/lokasi); +, rendah (1-50 ekor kutudaun/lokasi)

Berdasarkan hasil identifikasi pada preparat awetan pada mikroskop, $A$. gossypii memiliki bentuk kepala yang tidak berkembang, kauda agak mengecil pada bagian tengah dan sifunkulus berbentuk silindris. Brachycaudus sp. berwarna hijau kekuningan sampai hijau, memilikibentukkepalayang tidakberkembang, kauda berbentuk helm, sifunkulus memiliki bibir pada bagian pinggirnya dan ukurannya lebih pendek dibandingkan dengan sifunkulus A. gossypii (Gambar 2).

Pengaruh Periode Puasa Pra-Akuisisi dari A. gossypii terhadap Penularan Potyvirus

Periode puasa yang diberikan pada $A$. gossypii tidak berpengaruh terhadap penularan Potyvirus, hal tersebut disebabkan A. gossypii yang tidak dipuasakan mampu menularkan Potyvirus (Gambar 3), tetapi $A$. gossypii yang dipuasakan sebelum akuisisi menunjukkan persentase tanaman terinfeksi yang lebih tinggi. Periode puasa optimum ialah 25 menit dengan persentase tanaman terinfeksi sebesar $66.7 \%$ (30 hari setelah inokulasi (HSI)) dan 100\% (50 HSI).

\section{Pengaruh Periode Makan Inokulasi dari $A$. gossypii terhadap Penularan Potyvirus}

Kutudaun A. gossypii mampu menularkan Potyvirus setelah periode inokulasi 5 menit dengan persentase tanaman terinfeksi sebesar 30\% dengan masa inkubasi 50 hari (Gambar 4). Semakin lama periode inokulasi makan maka persentase tanaman terinfeksi semakin meningkat. Periode inokulasi optimum ialah 4 jam (Gambar 4). 


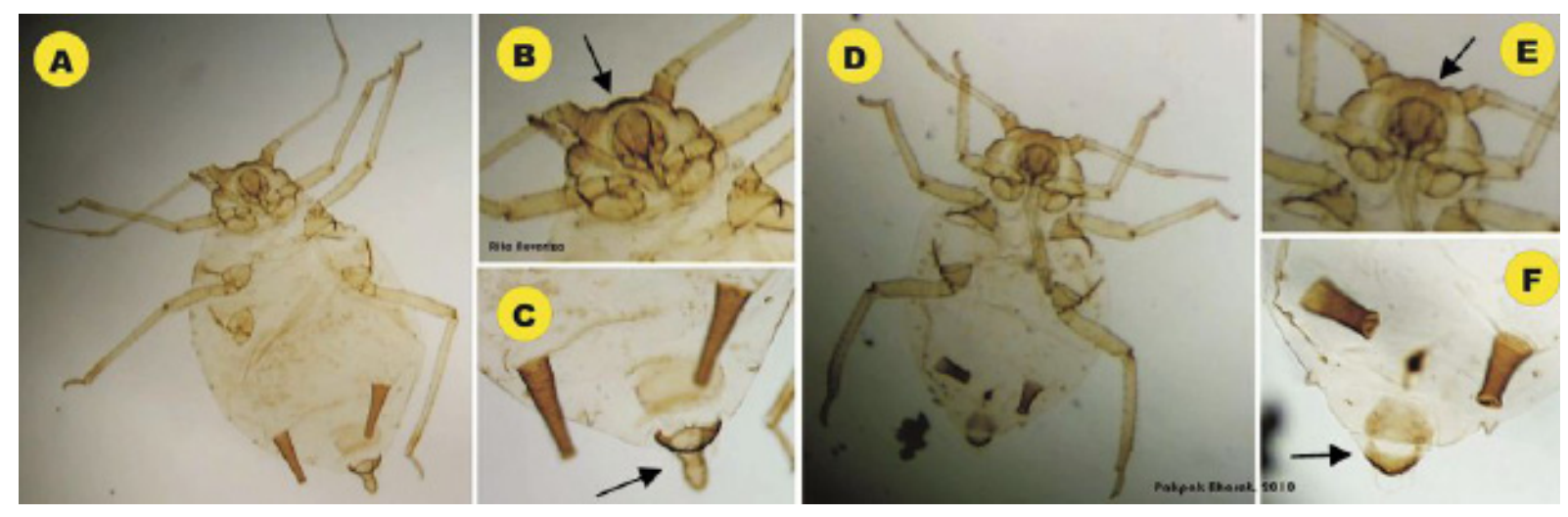

Gambar 2 A, Aphis gossypii dewasa aptera; B, kepala A. gossypii; C, kauda A. gossypii; D, Brachycaudus sp. dewasa aptera; E, kepala Brachycaudus sp.; dan F, kauda Brachycaudus sp.

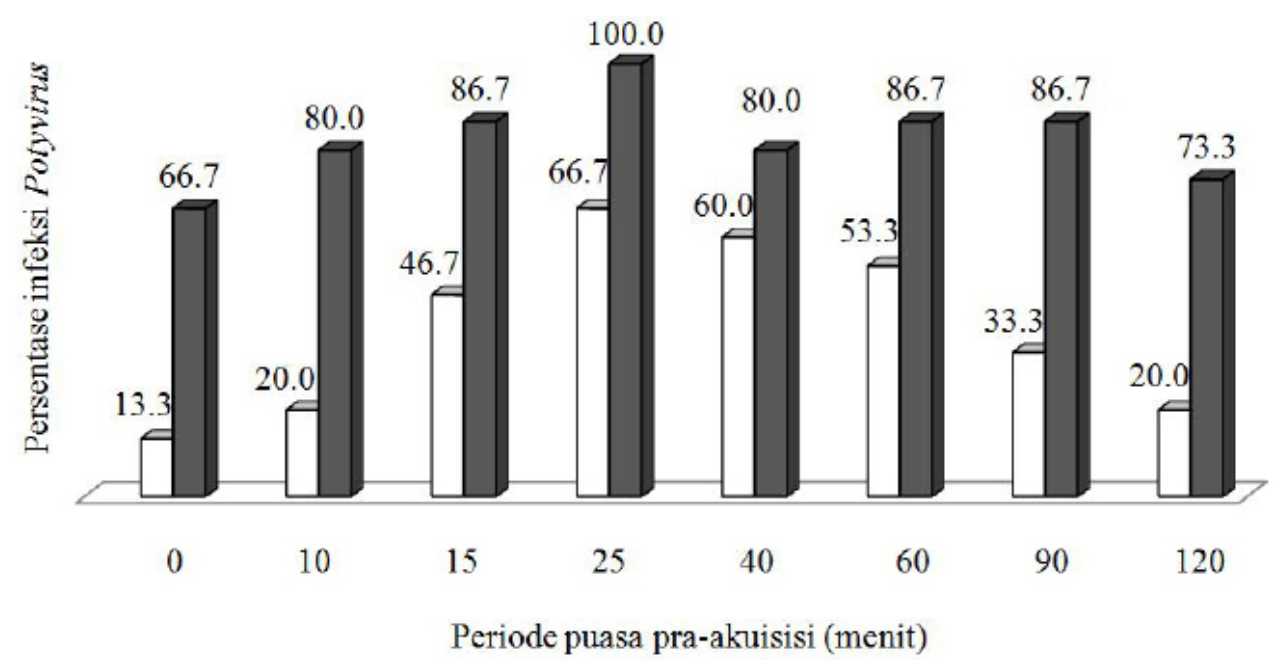

Gambar 3 Persentase infeksi Potyvirus yang ditularkan oleh Aphis gossypii pada beberapa tingkat periode puasa pra-akuisisi pada $30(\square)$ dan $50(\boldsymbol{\square})$ hari setelah inokulasi.

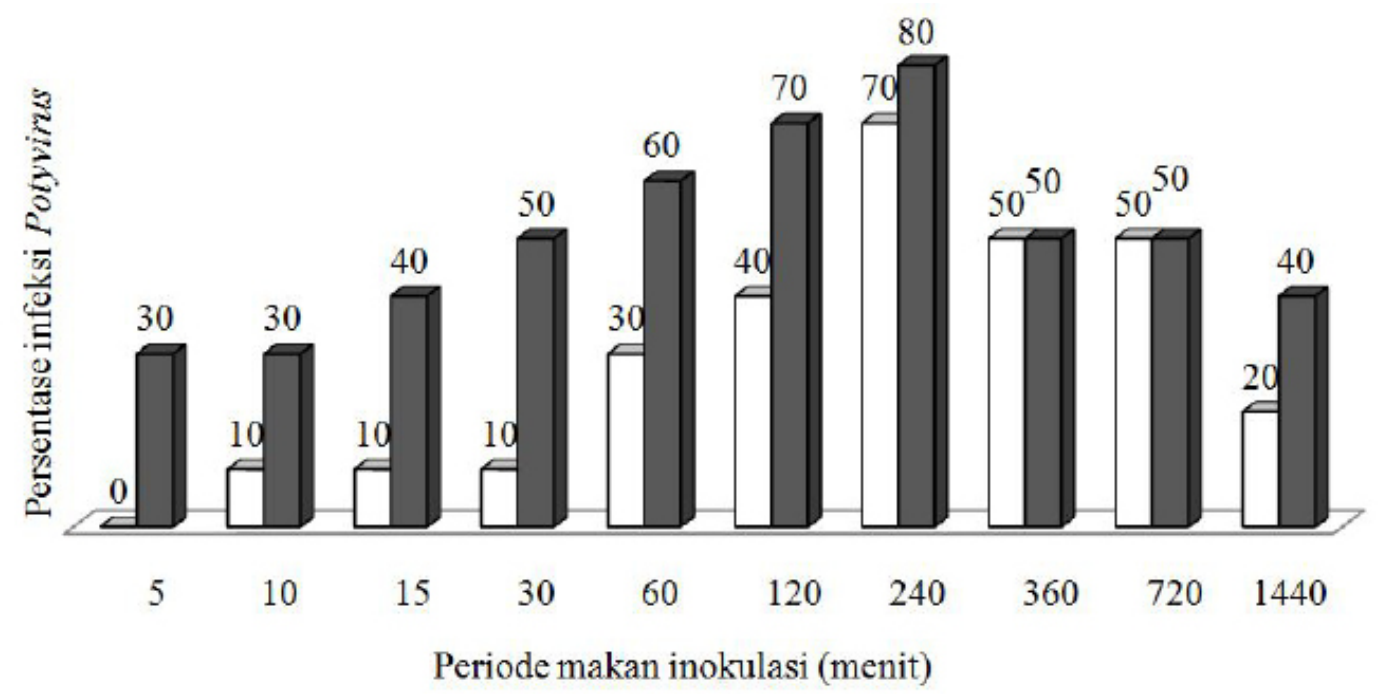

Gambar 4 Persentase infeksi Potyvirus yang ditularkan oleh Aphis gossypii pada beberapa tingkat periode makan inokulasi pada $30(\square)$ dan $50(\square)$ hari setelah inokulasi. 


\section{PEMBAHASAN}

Hasil identifikasi kutudaun menggunakan kunci identifikasi menunjukkan bahwa kutudaun yang yang ditemukan mengoloni tanaman nilam adalah $A$. gossypii dan Brachycaudus sp. Myzus persicae, yang pernah dilaporkan mengoloni tanaman nilam oleh Natsuaki et al. (1994), tidak ditemukan dalam survei ini.

A. gossypii dan Brachycaudus sp. bewarna hijau kekuningan sampai hijau, sehingga secara kasat mata cukup sulit membedakan keduanya. Tetapi jika dilihat dibawah mikroskop dapat dibedakan dari bentuk kauda dan sifunkulusnya. Menurut Blackman dan Eastop (2000), sifunkulus Brachycaudus sp. meruncing kearah ujung dan memiliki bibir pada bagian ujungnya, sedangkan $A$. gossypii meruncing dari pangkal sampai bagian tengah dan hampir lurus dari bagian tengah sampai ke ujung. Kauda Brachycaudus sp. berbentuk helm, sedangkan kauda $A$. gossypii agak mengecil pada bagian tengah.

Sebelumnya belum ada laporan yang menyatakan keberadaan Brachycaudus pada tanaman nilam, jadi perlu dipelajari bagaimana siklus hidup serangga ini pada tanaman nilam. Ada kemungkinan bahwa tanaman nilam bukanlah inang primer dari serangga Brachycaudus. Menurut Jousselin et al. (2010), Brachycaudus membutuhkan tanaman inang sekunder untuk melengkapi siklus hidupnya dan beberapa spesies dari Brachycaudus membutuhkan tanaman kelompok Lamiaceae (yang merupakan famili dari tanaman nilam) sebagai tanaman inang sekunder.

Penularan virus tumbuhan oleh serangga vektor (kutudaun) meliputi periode makan serangga vektor memperoleh virus (periode akuisisi) dari sumber virus yang berupa tanaman sakit atau tumbuhan lain, sehingga serangga mengandung virus (viruliferous) dan infektif. Vektor infektif kemudian menularkan virus yang dibawanya ke tanaman lain (periode inokulasi). Diantara waktu tertentu yang disebut masa inkubasi virus dalam tubuh vektor atau masa laten. Setelah menularkan virus ke tumbuhan lain, infektivitas vektor dapat hilang, menurun atau tetap sampai seumur hidup, tergantung dari pada tipe interaksi virus dengan serangga vektor (Nault 1997).

Berdasarkan hasil yang diperoleh pada penelitian ini, jelas dibuktikan bahwa hubungan antara penyakit mosaik pada nilam yang disebabkan oleh Potyvirus dan vektor $A$. gossypii ialah non-persisten. Hal yang sama dilaporkan oleh Singh et al. (2005) untuk Sunflower mosaic potyvirus (Potyvirus yang menyebabkan penyakit mosaik pada tanaman bunga matahari) yaitu, ditularkan secara non-persisten oleh $A$. craccivora. Demikian pula $A$. gossypii dan $M$. persicae menularkan Papaya ringspot virus-tipe $\mathrm{w}$ dan Zucchini yellow mosaic virus (Potyvirus) secara non persisten pada tanaman zucchini squash (Pinto et al. 2008), tanaman melon (Martin et al. 2003). Penularan virus oleh serangga secara non-persisten terjadi bila virus bertahan dalam tubuh serangga dalam waktu yang sangat singkat, beberapa menit atau jam. Serangga menjadi infektif dengan seketika setelah menghisap virus, tidak diperlukan periode laten. Persistensi atau retensi virus dalam vektor sangat singkat (Sylvester 1980). Kutudaun virulifer yang tidak menginokulasi tanaman lain juga kehilangan infektivitasnya setelah beberapa saat (Sumardiyono et al. 1997).

A. gosyypii yang dipuasakan dan yang tidak dipuasakan ternyata sama-sama mampu menularkan Potyvirus pada tanaman nilam, meskipun demikian dengan dipuasakan persentase infeksi Potyvirus lebih tinggi dibandingkan dengan yang tidak dipuasakan. Hal ini sesuai dengan penelitian yang dilakukan oleh Wang dan Pirone (1996) dan Singh et al. (2005). Puasa juga dapat menghilangkan komponen tanaman yang mengganggu retensi virion dalam kanal makanan yang ada pada stilet kutudaun (Wang dan Pirone1996).

Percobaan yang dilakukan pada pengaruh periode inokulasi terhadap kemampuan $A$. gossypii dalam menularkan Potyvirus menunjukkan bahwa kutudaun tersebut dapat menularkan virus dalam waktu 5 menit. 
Persentase infeksi meningkat dengan meningkatnya periode inokulasi sampai dalam waktu 4 jam, selanjutnya mulai menurun seiring dengan perpanjangan periode inokulasi (Gambar 4). Hal ini sesuai dengan penelitian yang dilakukan oleh Singh et al. (2005).

Seluruh tanaman yang diuji ternyata rentan terhadap Potyvirus, hal ini ditunjukkan oleh persentase infeksi Potyvirus mencapai 100\% setelah ditularkan oleh A. gossypii. Menurut Kishaba et al. (1992), persentase infeksi Watermelon mosaic virus yang ditularkan oleh A. gossypii pada tanaman yang rentan mencapai $97.9 \%$, pada tanaman yang toleran $69.4 \%$ dan pada tanaman yang tahan mencapai $26.7 \%$

Kutudaun yang mengoloni tanaman nilam didominasi oleh $A$. gossypii Glover dan kemudian oleh Brachycaudus sp. Kedua jenis kutudaun diperoleh di semua lokasi survei. Studi lebih lanjut mengetahui kemampuan $A$. gossypii menularkan Potyvirus, menunjukkan bahwa periode puasa pra-akuisisi optimum adalah 25 menit, periode akuisisi 15 menit dan periode makan inokulasi optimum 4 jam.

Kemampuan Brachycaudus sp. menularkan Potyvirus perlu dipelajari lebih lanjut karena keberadaan spesies kutudaun ini pada tanaman nilam di Indonesia belum pernah dilaporkan sebelumnya.

\section{UCAPAN TERIMA KASIH}

Penelitian ini dibiayai oleh beasiswa dan proyek penelitian dari Badan Penelitian dan Pengembangan Pertanian (Badan Litbang) Kementerian Pertanian. Ucapan terima kasih yang sebesar-besarnya juga penulis haturkan kepada Dewi Sartiami, Aisyah dan Elsa yang telah membimbing dan membantu penulis dalam melakukan identifikasi kutudaun pada tanaman nilam.

\section{DAFTAR PUSTAKA}

Blackman RL, Eastop VF. 2000. Aphids on the World,s Crops. An Identification and Information Guide. Ed ke-2. New York (US): Wiley.
Jousselin E, Genson G, Coeur d'acier A. 2010. Evolutionary lability of a complex life cycle in the aphid genus Brachycaudus. BMC Evol Biol. 10:1-15. doi: 10.1186/1471-2148-10295

Kishaba AN, Castle SJ, Coudriet DL, McCreight JD, Bohn GW. 1992. Virus transmission by Aphis gossypii Glover to aphid-resistant and susceptible muskmelons. J Amer Soc Hort Sci. 117(2):248254.

Martin JH. 1983. The identification of common Aphid pest of tropical agriculture. Tropi Pest Manag. 29(4):395-411. doi:10.1080/ 09670878309370834.

Martin B, Rahbe Y, Fereres A. 2003. Blockage of stylet tips as the mechanism of resistance to virus transmission by Aphis gossypii in melon lines bearing the Vat gene. Ann Appl Biol. 142(2):245-250. doi: 10.1111/ j.1744-7348.2003.tb00247.x.

Natsuaki KT, Tomaru K, Ushiku S, Ichikawa Y, Sugimura Y, Natsuaki T, Okuda S, Teranaka M. 1994. Characteristic of two viruses isolated from patchouli in Japan. Plant Dis. 78(11):1094-1097. doi: 10.1094/ PD-78-1094.

Nault LR. 1997. Arthropod transmission of plant viruses. A new synthesis. Ann Ent Soc America. 90(5):521-541.

Noveriza R, Suastika G, Hidayat SH and Kartosuwondo U. 2012. Potyvirus associated with mosaic disease on patchouli plants in Indonesia. ISSAAS J. 18(1):131-146.

Pinto ZV, Rezende JAM, Yuki VA, Piedade SMS. 2008. Ability of Aphis gossypii and Myzus persicae to transmit Cucumber mosaic virus in single and mixed infection with two potyviruses to zucchini squash. Summa Phytopathol. 34(2):183-185. doi: 10.1590/S01005405200800 0200016.

[PDIP] Pusat Data Informasi Pertanian. 2010. Outlook Komoditas Pertanian Perkebunan. Jakarta (ID): Kementerian Pertanian.

Singh RK, Singh SJ, Prakash S. 2005. Relationship of Sunflower mosaic potyvirus (SMPV) with its aphid vector Aphis craccivora Koch. Ind J Agr Res. 39(1):1-9. 
Sularno. 2009. Pengaruh lama waktu makan akuisisi dan lama waktu makan inokulasi Myzus persicae dan Aphis glycine terhadap kecepatan penularan virus tanaman. Kultura. 10(1):1-6.

Sumardiyono YB, Supratoyo, Samsuri. 1997. Penularan penyakit mosaik kacang panjang oleh Aphis craccivora. J Perlin Tan Indones. 3(1):32-37.
Sylvester ES. 1980. Circulative and propagative virus transmission by aphids. Ann Rev Entomol. 25(1):257-286. doi: 10.1146/annurev.en.25.010180.001353.

Wang RY, Pirone TP. 1996. Potyvirus transmission is not increased by preacquisition fasting of aphids reared on artificial diet. J Gen Virol. 77(12):31453148. doi: 10.1099/0022-1317-77-12-3145. 